\title{
SENAM KAKI UNTUK MELANCARKAN AIRAN DARAH PERIFER PASIEN DIABETES MELLITUS TIPE 2
}

\author{
Yulis Hati ${ }^{1}$, Rosanti Muchsin ${ }^{2}$ \\ Universitas Haji Sumatera Utara, Deli Serdang \\ yoelisht@gmail.com, rosantimuchsin02@gmail.com
}

\begin{abstract}
ABSTRAK
Penyakit diabetes mellitus merupakan penyakit kronis yang tidak dapat disembuhkan akan tetapi dapat dikendalikan. Pengendalian penyakit DM salah satunya adalah dengan latihan jasmani. Latihan jasmani salah satunya senam kaki akan menyebabkan terjadinya peningkatan aliran darah, maka akan lebih banyak jala-jala kapiler terbuka sehingga lebih banyak tersedia reseptor insulin dan reseptor menjadi lebih aktif yang akan berpengaruh terhadap penurunan glukosa darah pada peserta diabetes. Penderita DM di Desa Kubah Sentang Kecamatan Pantai Labu tahun 2019 cukup banyak dan belum pernah melakukan senam kaki diabetes. Pelaksanaan senam kaki diabetes dilakukan sebanyak 6 kali selama dua minggu. Peserta yang mengikuti sebanyak 24 orang, setelah rutin melakukan senam kaki diabetes merasakan kesemutan di kakinya jarang terjadi ini karena manfaat senam kaki adalah untuk memperbaiki sirkulasi darah yang terganggu, memperbaiki kekuatan otot, melatih kaki dan sendi agar tetap lentur dan mencegah komplikasi diabetes.
\end{abstract}

Kata kunci: Senam Kaki Diabetes, Diabetes Mellitus

\begin{abstract}
Diabetes mellitus is a chronic disease that cannot be cured but can be controlled. One of the ways to control DM is through physical exercise. Physical exercise, one of which is leg exercises, will cause an increase in blood flow, so that more capillary nets will open so that more insulin receptors are available and receptors become more active which will affect the decrease in blood glucose in diabetic participants There were quite a number of DM sufferers in Kubah Sentang Village, Pantai Labu District in 2019 and had never done diabetic foot exercises. The diabetic foot exercise was carried out 6 times for two weeks. Participants who followed as many as 24 people, after routinely doing diabetic foot exercises, felt tingling in their feet rarely because the benefits of foot exercises were to improve blood circulation, improve muscle strength, train legs and joints to stay flexible and prevent diabetes complications
\end{abstract}

Keywords: Diabetes Foot Exercise, Diabetes Mellitus

\section{Pendahuluan}

Penyakit diabetes mellitus (DM) merupakan penyakit kronis yang tidak dapat disembuhkan tetapi dapat dikendalikan. (Ruben, Rottie and Karundeng, 2016). DM merupakan penyakit menahun yang akan disandang seumur hidup. Pengelolaan penyakit ini memerlukan peran serta dokter, perawat, ahli gizi, dan tenaga kesehatan lain. Penderita DM dan keluarga juga ikut berperan untuk ikut serta mendapatkan edukasi untuk memberikan pemahaman mengenai perjalanan penyakit, pencegahan, penyulit, dan penatalaksanaan DM (Rudianto, 2011).

Semakin tinggi prevalensi DM dikhawatirkan akan meningkatkan terjadinya komplikasi dimana akan meninngkatkan resiko penyakit penyerta. Komplikasi yang terjadi 
pada DM di Indonesia diantaranya adalah komplikasi neuropati $60 \%$, penyakit jantung koroner $20,5 \%$, ulkus diabetika $15 \%$, retinopati $10 \%$, dan nefropati $7,1 \%$ (Satriawibawa and Saraswati, 2014). Terjadinya kompikasi kronik DM salah satunya adalah adanya neuropati perifer yang akan menyebabkan terjadinya gangguan sensorik akan menyebabkan hilang atau menurunya sensasi nyeri pada kaki, sehingga akan mengalami trauma tanpa terasa mengakibatkan terjadinya atrofi otot kaki, sehingga titik tumpu yang menyebabkan ulsetrasi pada kaki pasien. Untuk mengurangi neuropati perifer sebaiknya dilakukan latihan jasmani. Komponen latihan jasmani atau olahraga sangat krusial pada penatalaksanaan DM sebab efeknya bisa menurunkan kadar glukosa darah dengan pengambilan glukosa oleh otot terus meningkat seiring dengan memperbaiki pemakaian insulin (Rudianto, 2011)

Latihan jasmani akan mengakibatkan terjadinya peningkatan aliran darah, maka jala-jala kapilerakan banyak yang terbuka sebagai akibatnya reseptor insulin akan banyak tersedia dan lebih aktif yang akan berpengaruh terhadap penurunan glukosa darah pasien DM (Hati, 2014). Latihan jasmani sebaiknya disesuaikan dengan usia dan status kesegaran jasmani. Pasien DM tipe 2 yang relatif sehat dapat meningkatkan intensitas latihan jasmani, sedangkan pasien DM tipe 2 yang mengalami komplikasi dapat mengurangi intensitas, salah satu yang dianjurkan adalah senam kaki diabetes (Soelistijo et al., 2015)

Senam kaki diabetes merupakan latihan jasmani untuk penderita DM atau bukan penderita untuk mencegah terjadinya luka dan membantu melancarkan peredaran darah bagian kaki (Flora and Purwanto, 2014). Senam kaki cara yang tepat untuk melancarkan sirkulasi terutama ke daerah kaki, salah satunya yaitu senam aerobic yang variasi gerakannya pada daerah kaki memenuhi kriteria continous, rhythmical, interval, progresif dan endurance sehingga setiap tahapan gerakan harus dilakukan (Wahyuni, 2016). Senam yang direkomendasikan dilakukan dengan intensitas moderat (60-70 maksimum heart rate), durasi 30-60 menit, dengan frekuensi 3-5 kali per minggu dan tidak lebih dari dua hari berturut-turut melakukan senam (Ruben, Rottie and Karundeng, 2016).

Berdasarkan survey yang dilakukan di desa Kubah Sentang Kec. Pantai Labu Kabupaten Deli Serdang tahun 2019 banyak yang menderita DM khususnya lansia. Dimana penderita DM merasakan kebas di kaki, kesemutan dan terkadang tidak merasa apa-apa. Setelah didata terdapat 42 orang menderita penyakit DM dan belum pernah melakukan senam kaki diabetes.

Adapun tujuan pengabdian adalah untuk menambah pengetahuan dan peseta bisa melakukan senam kaki diabetes sebagai latihan jasmani guna menurunkan neuropati perifer pada pasien DM Tipe 2.

\section{Pelaksanaan dan Metode}

Dari data hasil survey dijadikan acuan dalam melaksanakan kegiatan. Kegiatan senam kaki di lakukan di rumah kader posyandu karena tempat memungkinkan untuk dilakukan senam kaki diabetes yang dilaksanakan selama dua minggu (seminggu 3 kali). Metode dalam pengabdian ini menggunakan ceramah berupa pendidikan kesehatan, diskusi dan praktek senam kaki diabetes. Kegiatan ini dengan menggunakan video dan leaflet, laptop, LCD Projector, kursi dan koran.

Prosedur senam kaki diabetes yaitu:

1. Peserta duduk di kursi dengan tegak dengan kaki menyentuh lantai. 
2. tumit diletakkan dilantai kemudian jari-jari kaki kanan dan kiri diluruskan kearah atas kemudian dibengkokkan kembali (seperti cakar ayam), hal ini dilakukan sebanyak 10 kali.

3. letakkan salah satu tumit dilantai kemudian angkat telapak kaki ke atas. sebaliknya pada kaki yang lainnya, jari-jari kaki diletakkan di lantai dan tumit kaki diangkatkan ke atas. Gerakan ini dilakukan secara bersamaan pada kaki kanan dan kiri bergantian dan diulangi 10 kali.

4. Tumit kaki diletakkan di lantai. Kemudian bagian Ujung jari kaki diangkat ke atas \& untuk gerakan memutar dalam pergelangan kaki, lakukan 10 kali.

5. Jari-jari kaki diletakkan dilantai. Kemudian tumit diangkat \& untuk gerakan memutar menggunakan pergerakkan dalam pergelangan kaki, ulangi gerakan 10 kali.

6. Angkat salah satu lutut kaki, dan luruskan. Lalu gerakan jari-jari kaki kedepan kemudian turunkan kembali secara bergantian kekiri dan ke kanan. Ulangi gerakan ini sebanyak 10 kali.

7. Luruskan salah satu kaki diatas lantai kemudian angkat kaki tersebut dan gerakkan ujung jari-jari kaki kearah wajah lalu turunkan kembali kelantai

8. Angkat kedua kaki bersamaan lalu luruskan. Gerakan diulang 10 kali

9. Angkat kedua kaki dan luruskan,pertahankan posisi tersebut. Kemudian gerakan pergelangan kaki kedepan dan kebelakang.

10. Luruskan salah satu kaki dan angkat, lalu putar kaki pada pergelangan kaki, lakukan gerakan seperti menulis di udara dengan kaki dari angka 0 hingga 10 lakukan secara bergantian.

11. Letakkan selembar koran dilantai. Kemudian bentuk koran tadi seperti bola menggunakan ke 2 kaki. Lalu buka kembali bola tadi menggunakan jari menjadi lembaran seperti bentuk semula. Gerakan ini dilakukan hanya sekali saja..

12. Robek koran tadi menjadi 2 bagian dengan menggunakan jari kaki, lalu pisahkan kedua bagian koran tersebut.

13. Satu bahagian koran di sobek-sobek menjadi kecil-kecil dengan kedua kaki.

14. Pindahkan kumpulan sobekan-sobekan tersebut dengan kedua kaki lalu letakkan pada bagian kertas yang utuh tadi.

15. Lalu bungkus semua sobekan-sobekan tadi dengan kedua kaki menjadi bentuk bola. (Flora and Purwanto, 2014)

\section{Hasil dan Pembahasan}

\section{Hasil}

Pelaksanaan senam kaki dilakukan di Desa Kubah Sentang Kecamatan Pantai Labu Kabupaten Deli Serdang. Jumlah peserta yang mengikuti senam kaki pada hari pertama sebanyak 32 orang, namun di pertemuan kedua dan seterusnya sampai petemuan keenam yang tetap mengikuti jadwal senam kaki sebanyak 24 orang.

Senam kaki dilaksanakan seminggu 3 kali selama dua minggu, dengan jadwal pada pagi hari jam 09.00 - 10.00 yang dilaksanakan di rumah kader posyandu. Kegiatan dimulai dengan pemaparan pengertian, tujuan manfat dan cara melakukannya senam kaki diabetes mellitus yang dilihat melalui vidio. Penderita DM tipe 2 masih belum jelas karena belum mengetahui bagaimana melakukan senam kaki diabetes tersebut. 


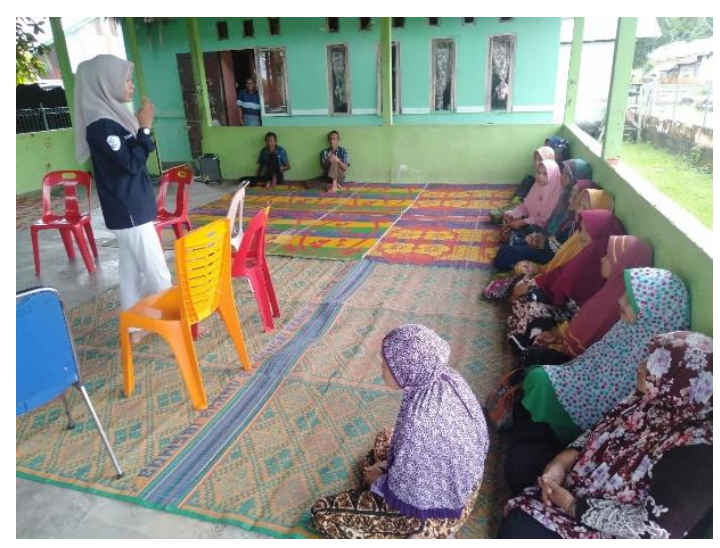

Gambar 1. Menerangkan pengertian, tujuan dan manfaat senam kaki

Setelah dijelaskan tentang pengertian, tujuan manfaat dan prosedur senam kaki, kemudian peserta duduk di kursi yang telah disediakan. Dan melakukan senam kaki diabetes dengan mengikuti video dan dibimbing oleh beberapa orang
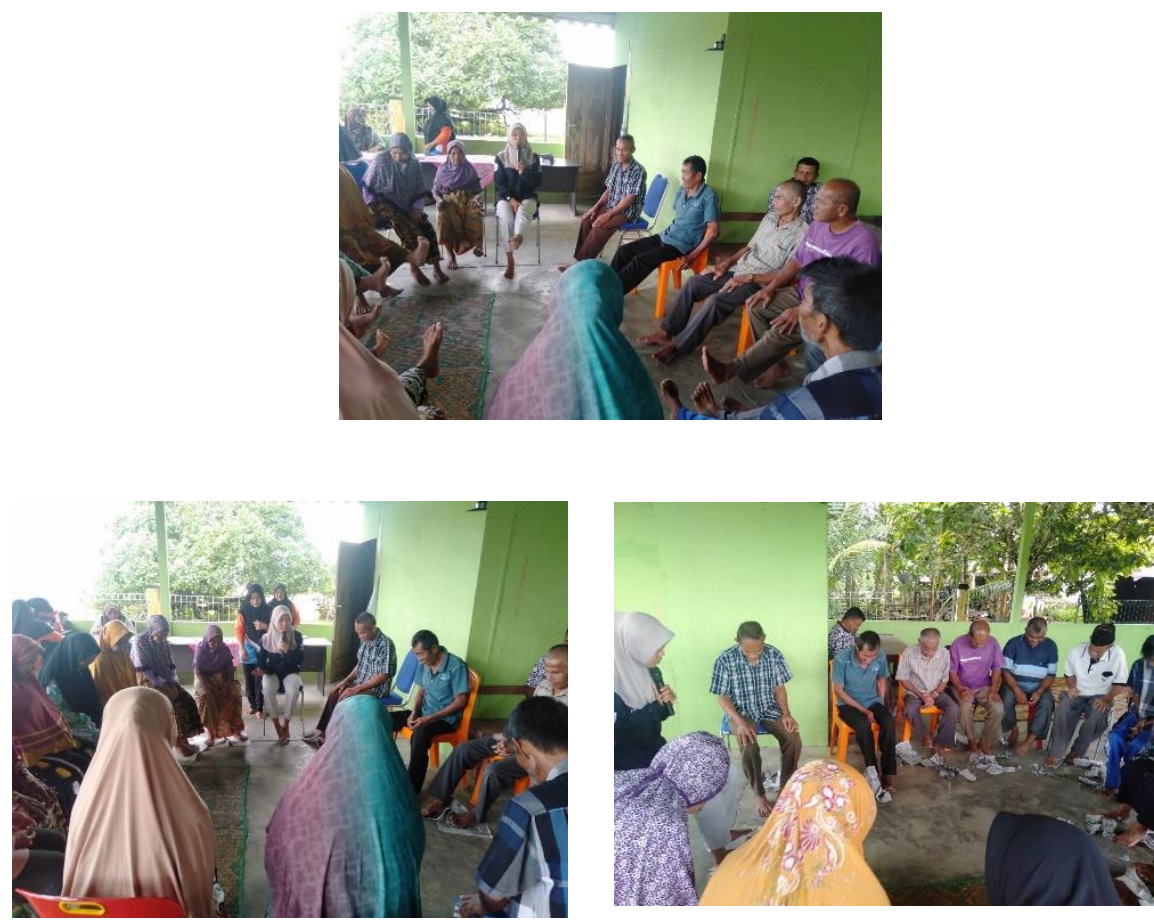

Gambar 2. Pelaksanaan Senam Kaki Diabetes

Pelaksanaan senam kaki hari berikutnya sampai 6 kali senam didapatkan peserta DM sudah bisa melakukan senam tersebut secara mandiri dan mereka mengatakan kaki 
mereka lebih baik, lebih berasa dan kesemutan jarang terjadi jadi mereka semangat melakukan senam kaki seminggu 3 kali dan bisa dilakukan kapan saja tanpa melihat waktu pelaksanaan.

\section{Pembahasan}

Kegiatan ini merupakan kegiatan pengabdian masyarakat yang dilakukan oleh staf pengajar STIKes RS Haji Medan yang mengemban mata kuliah Keperawatan Medikal Bedah.

Setelah enam kali dilakukan senam kaki diabetes di desa Kubah Sentang Kecamatan Pantai Labu didapatkan dari hasil wawancara dan pernyataan peserta yang rutin mengikuti kegiatan bahwa peserta merasakan kakinya lebih baik dan kesemutan sudah jarang terjadi. Hasil pernyataan peserta juga dilatar belakangi oleh faktor kontinuitas atau keteraturan peserta dalam mengikuti senam sehingga terjadi penurunan kadar gula darah. Olahraga atau latihan fisik adalah bagian yang tidak dapat dipisahkan dalam merawat penderita DM disamping mentaati diet (terapi nutrisi medis), dan pemakaian obat-obatan baik penderita DM Tipe 1 maupun tipe 2 (Mulianingsih, Bahtiar and Nurmayani, 2021)

Dari hasil pemamapan peserta yang telah melakukan senam kaki diabetes maka sangat bermanfaat mekukan latihan jasmani tersebut, dimana manfaatnya adalah memperbaiki sirkulasi darah yang terganggu, memperbaiki kekuatan otot, melatih kaki dan sendi agar tetap lentur dan mencegah komplikasi diabetes (Pratiwi. dkk, 2019)

Penderita DM yang sudah lebih dari tiga tahun diderita tentunya punya komplikasi akut antara lain neuropati perifer yaitu gangguan yang terjadi akibat kerusakan pada sistem saraf perifer atau sistem saraf tepi. Kerusakan tersebut menyebabkan proses pengiriman sinyal antara sistem saraf pusat dan sistem saraf tepi terganggu, ini sering terjadi pada pasien DM terutama yang lansia. Proses penuaan yang menyebabkan perubahan dinding pembuluh darah sebagai akibatnya mempengaruhi transportasi oksigen dan nutrisi ke jaringan. Lapisan intima menebal menjadi dampak proliferasi seluler juga fibrosis. Serabut pada lapisan media mengalami kalsifikasi,tipis, terpotong, dan kolagen yang menumpuk pada lapisan intimadan media. Perubahan tadi mengakibatkan kekakuan pembuluh darah, dapat menyebabkan peningkatan tekanan pembuluh perifer,ganguan aliran darah juga peningkatan kerja ventrikel kiri. (Smeltzer, 2008)

Senam kaki diabetes yang telah dilakukan dengan rutin dan teratur sesuai dengan petunjuk (6 kali dilakukan selama dua minggu) oleh peserta sangat berdampak pada setiap individu karena dengan melakukan gerakan-gerakan dalam senam tersebut berguna untuk melancarkan sirkulasi darah dikaki dan mencegah komplikasi. Jenis olahraga yg dianjurkan untuk pasien DM yaitu olahraga yang bersifat rekreasional juga profesional. Senam kaki bersifat rekreasional ialah bisa menjadi hiburan yang tidak menharuskan dilakukan ditempat tertentu, senam kaki bisa dilakukan sendiri dirumah, hemat energy, waktu, dan uang. Sedangkan profesional ialah senam kaki apabila dilakukan secara teratur bisa menaikkan kualitas kesehatan yang professional. Hindari olah raga yang kontak dengan tubuh (Mulianingsih, Bahtiar and Nurmayani, 2021).

\section{Kesimpulan}


Berdasarkan hasil kegiatan pengabdian masyarakat yang telah dilakukan ini, dapat dilihat bahwa kegiatan Senam kaki ini diperlukan untuk penderita diabetes mellitus di desa Kubah Sentang Kecamatan Pantai Labu tahun 2019. Senam kaki diabetes dilakukan selama dua minggu, 3 kali dalam seminggu. Dimulai dengan edukasi tentang defenisi, tujuan, manfaat dan prosedur senam kaki diabetes yang dilanjutkan dengan pelaksanaan senam selama 6 kali. Peningkatan kemampuan dalam praktik senam kaki diabetes sebagai upaya menghindari resiko terjadinya komplikasi DM antara lain, ulkus diabetikum dan neuropati perifer.

Peserta mengikuti senam kaki secara rutin karena sangat bermanfaat bagi mereka. Dan dapat dilakukan secara teratur dirumah dan gerakannya disesuaikan dengan kemampuan tubuh. Dapat dilakukan pula sambil bersantai bersama keluarga, mudah dan kaya akan manfaat sehingga diharapkan derajat kesehatan penderita meningkat dan terhindar dari resiko komplikasi pada kaki diabetes.

Seluruh peserta merasakan kakinya lebih baik dan kesemutan sudah jarang terjadi dan mereka bersedia melakukan senam secara rutin karena mereka sudah tau dan menguasai prosedur senam kaki diabetes yang sudah diajarkan.

\section{Ucapan Terimakasih}

Pengabdian masyarakat ini telah selesai salah satunya adalah terlibatnya berbagai pihak sebagai pendukung, untuk itu peneliti mengucapkan terimakasih kepada

1. Kepada Ketua STIKes RS Haji Medan yang sudah memberikan izin kepada saya untuk melaksanakan kegiatan ini

2. Kepala desa Kubah Sentang Kecamatan Pantai Labu Kabupaten Deli Serdang telah memberikan kepercayaan untuk pelaksanaan kegiatan ini

3. Para peserta yang merupakan warga desa Kubah Sentang telah mengikuti kegiatan senam kaki diabetes.

\section{Referensi}

Flora, R. and Purwanto, S. (2014) 'Pelatihan Senam Kaki Pada Penderita Diabetes Komplikasi Diabetes Pada Kaki ( Diabetes Foot )', Unsri.Ac.Id, pp. 7-15.

Hati, Y. (2014) 'Efektifitas Edukasi Diabetes Terpadu Untuk Meningkatkan Efikasi Diri Pasien Diabetes Melitus Tipe 2', Universitas Sumatera Utara.

Mulianingsih, M., Bahtiar, H. and Nurmayani, W. (2021) 'Penurunan Gula Darah Pasien Diabetes Melitus Tipe 2 Dengan Senam Kaki Puskesmas Ubung Lombok Tengah', Lentera Jurnal, 1(1), pp. 1-7. doi: 10.26714.

Pratiwi. dkk (2019) 'Fake ( Foot and Ankle Exercises ) Untuk Pencegahan Komplikasi', 1(1), pp. 8-13.

Ruben, G., Rottie, J. and Karundeng, M. Y. (2016) 'Pengaruh Senam Kaki Diabetes Terhadap Perubahan Kadar Gula Darah Pada Pasien Diabetes Melitus Tipe 2', eJournal Keperawatan (eKp), 4, pp. 1-5.

Rudianto, A. D. (2011) Konsnsus Pengelolaan dan Pencegahan Diabetes Melitus Tipe 2 di Indonesia 2011.

Satriawibawa, I. and Saraswati, M. (2014) 'Prevalensi Komplikasi Akut Dan Kronis 
Pasien Diabetes Melitus Tipe 2 Di Poliklinik Penyakit Dalam Rsup Sanglah Periode Januari 2011- Mei 2012', E-Jurnal Medika Udayana, 3(10), pp. 1-15.

Smeltzer, S. C. . B. G. B. (2008) Buku Ajar Keperawatan Medikal-Bedah Brunner \& Suddarth. 2nd edn. Jakarta: EGC.

Soelistijo, S. et al. (2015) Konsesus Pengelolaan Dan Pencegahan Diabetes Melitus Tipe2 Di Indonesia 2015, PERKENI.

Wahyuni, A. (2016) 'Senam Kaki Diabetik Efektif Meningkatkan Ankle Brachial Index Pasien Diabetes Melitus Tipe 2', Jurnal Ipteks Terapan, 9(2), pp. 155-164. doi: 10.22216/jit.2015.v9i2.231. 